\title{
Erratum to: Plasma Nitriding Behavior of Fe-C-M (M = Al, Cr, Mn, Si) Ternary Martensitic Steels
}

\author{
YUSAKU TOMIO, SHIGEKI KITSUYA, KEIICHIRO OH-ISHI, KAZUHIRO HONO, \\ GORO MIYAMOTO, and TADASHI FURUHARA
}

DOI: $10.1007 / \mathrm{s} 11661-013-2058-3$

(C) The Minerals, Metals \& Materials Society and ASM International 2013

\section{Erratum to: METALLURGICAL AND MATERIALS \\ TRANSACTIONS A \\ DOI: 10.1007/s11661-013-1991-5}

Keiichiro Oh-ishi's given name is correct as presented in this erratum.

YUSAKU TOMIO, formerly Graduate Student with the Graduate School of Engineering, Tohoku University, Sendai 980-8577, Japan, is now Researcher with the Amagasaki Research and Development Center, Nippon Steel \& Sumitomo Metal Corporation, Amagasaki 660-0891, Japan. SHIGEKI KITSUYA, formerly with the Graduate School of Engineering, Tohoku University, is now Researcher with the Steel Research Laboratory, JFE Steel Corporation, Kurashiki 712-8511, Japan. KEIICHIRO OH-ISHI, formerly Post Doctoral Research Associate with the National Institute for Materials Science, Tsukuba 305-0047, Japan, is now with the Nagaoka University of Technology, Nagaoka 940-2188, Japan. KAZUHIRO HONO, NIMS Fellow, Director of the Magnetic Materials Unit, with National Institute for Materials Science, Tsukuba 305-0047, Japan. GORO MIYAMOTO, Associate Professor and TADASHI FURUHARA Professor, Deputy Director, are with the Institute for Materials Research, Tohoku University, Sendai 980-8577, Japan. Contact e-mail: furuhara@imr.tohoku.ac.jp

The online version of the original article can be found under doi: 10.1007/s11661-013-1991-5.

Article published online November 19, 2013 